GAP GYAN - An International Peer-Reviewed

Open Access Journal of Social Sciences

\title{
TRACING THE EVOLVING FACTS OF, A HUMAN RIGHT TO PRIVACY WITH INDIAN PERSPECTIVE
}

\author{
Ms. Heena Laxmandas Makhija \\ Phd Research Scholar, \\ University School of Law, Gujarat University, Ahmedabad \\ hinamakhija25@gmail.com \\ Dr. Bhavesh H. Bharad \\ Assistant Professor, \\ University School of Law, Gujarat University, Ahmedabad \\ dr.bharad@gmail.com
}

\begin{abstract}
Human Rights are basic rights and freedoms that belong to every person in world from birth until death. They apply of where you are from, what you believe or how you choose to live your life. Privacy is a concomitant of the right of an individual to exercise over his or her personality. There are certain rights which are natural to or inherent in human right. The human element in life is impossible to conceive without the existence of natural rights. It is very difficult to give precise definition of privacy; with the changing time the definition of privacy and its aspect has also changed. Article 12 of Universal Declaration of Human Rights recognize about the right to privacy. Article 51 of the Indian constitution requires the state to endeavor to foster respect for international law and treaty obligation in the dealings of organized people with one another. The present paper focuses on changing dimension of privacy law from the various judgments given by the judiciary, how the aspect of privacy has evolved from early cases till the day when right to privacy, a human right has been declared as fundamental right by Indian judiciary system.
\end{abstract}

KEYWORDS: Right to Privacy, Human Right, Constitution.

\section{INTRODUCTION}

Human rights are moral principles or norms ${ }^{15}$ that describe certain standards of human behavior and are regularly protected as natural and legal rights in municipal and international law ${ }^{16}$. They are commonly understood as inalienable ${ }^{17}$, fundamental rights "to which a person is inherently entitled simply because she or he is a human being"18 and which are "inherent in all human beings", ${ }^{19}$ regardless of their nation, location, language, religion, ethnic origin or any other status. They are applicable everywhere and at every time in the sense of being universal,

15 James Nickel, with assistance from Thomas Pogge, M.B.E. Smith, and Leif Wenar, December 13, 2013, Stanford Encyclopedia of Philosophy ,Human Rights, Retrieved August 14, 2014.

${ }^{16}$ Nickel 2010

${ }^{17}$ The United Nations, office of the High Commissioner of Human Rights, What are human rights?, Retrieved August 14, 2014

${ }^{18}$ Sepulveda et al. 2004, p.3 "Archieved copy". Archieved from the original on Maarch 28, 2012. Retrieved November8, 2011

${ }^{19}$ Burns H.Weston, March 20, 2014, Enclopedia Britannica, Human rights, Retrieved August14, 2014. 


\section{GAP GYAN - $\begin{aligned} & \text { An International Peer-Reviewed } \\ & \text { Open Access Journal of Social Sciences }\end{aligned}$}

and they are egalitarian in the sense of being the same for everyone. They are regarded as requiring empathy and the rule of law and imposing an obligation on persons to respect the human rights of others, and it is generally considered that they should not be taken away except as a result of due process based on specific circumstances. The right to privacy is an element of various legal traditions to restrain governmental and private actions that threaten the privacy of individuals ${ }^{20},{ }^{21}$. In recent years there have been only few attempts to clearly and precisely define the "right to privacy". One of which is the as "the right to privacy is our right to keep a domain around us, which includes all those things that are part of us, such as our body, home, property, thoughts, feelings, secrets and identity. The right to privacy gives us the ability to choose which parts in this domain can be accessed by others, and to control the extent, manner and timing of the use of those parts we choose to disclose ${ }^{22}$. A right to privacy is explicitly stated under Article 12 of the 1948 Universal Declaration of Human Rights: No one shall be subjected to arbitrary interference with his privacy, family, home or correspondence, nor to attacks upon his honor and reputation. Everyone has the right to the protection of the law against such interference or attacks. Privacy underpins human dignity and other key values such as freedom of association and freedom of speech. It has become one of the most important human rights issues of the modern age. The various reasons have been discussed for comprehensive privacy and data protection laws. Many countries are adopting these laws for few of important trends such as globalization, convergence, multimedia that contribute to privacy invasions. ${ }^{23}$ Article17 of the International Covenant on Civil and Political Rights (ICCPR)(1966) "the above legally protect persons against "arbitrary interference "with one's privacy , family, home , correspondence, honour and reputation". India has signed and ratified the ICCPR on April 10, 1979, without reservation. Article 7 and 8 of the Charter of Fundamental Rights of the European Union, 2012."Recognizes the respect for: private and family life, home and communications." Article 8 mandates: "protection of personal data and its collection for a specified legitimate purpose. Article 51of Directive Principle of State Policy in Indian Constitution states about promotion of international peace and security. The state shall endeavor to -promote international peace and security; maintain just and honorable relations between nations; foster respect for international law and treaty obligations in the dealings of organized peoples with one another; and encourage settlement of international disputes by arbitration Earlier the privacy was only attached only to property but with evolution of technology and democracy.

The notion of privacy has also expanded. Phone tapping, narco test and truth serum, Aadhar data linkage. Article 19(1) (f) and Article 20(3) of the Constitution were challenged in MP Sharma v Satish Chandra, District Magistrate Delhi ${ }^{24}$, by nine judge bench, where searches were violated the fundamental rights of the petitioners on an allegations that the company had indulged in fraudulent transactions and had falsified its records. Union government had ordered investigation under the companies act into the affairs of the company which was in liquidation on ground that it had made an organized attempt to embezzle its funds and had conceal its true state of its affairs from the shareholders and had indulged in fraudulent transactions and had falsified .Disregarding the

20 "The Privacy Torts"(December 19, 2000). Privacilla. Org.

21 "Right to Privacy"faculty.uml.edu. Retrieved 31 march 2018.

${ }^{22}$ Yael Onn, et al., Privacy in the Digital Environment, Haifa Center of law \&Technology, (2005)pp.1-12.

${ }^{23}$ GLOBAL INTENET LIBERTY CAMPAIGN, PRIVACY AND HUMAN RIGHS. AN INTENATIONAL SURVEY OF PRIVACY LAWS AND PRACTICE

${ }^{24}$ (1954) SCR 1077 


\section{GAP GYAN - An International Peer-Reviewed Open Access Journal of Social Sciences}

contention the court held that seizure was for temporary period of time not violating Article 20(3) of Constitution of India, while referring the judgment of US Supreme court, illegal seizures and search violated the fourth and Fifth Amendment's of the American constitution.

Articles 19(1) (d) and Article 21 of the Constitution were challenged in Kharak Singh and State of UP 25 being violated by the provisions of the U.P Police Regulation, where Supreme Court had the occasion to consider the ambit and scope of privacy right when the power of surveillance conferred on the police. The Court repelled the argument of infringement of freedom guaranteed under Article 19(1) (d) of the Constitution, and the attempt to ascertain the movements of an individual was held not to be an infringement of any fundamental right. The word privacy' was defined where contentions and the evolution of Right to privacy stated in Govind v. State of M.P26and R. Rajagopal v. State of T.N27, as "right to be left alone "and was held that every citizen had a right to safeguard the privacy of his own, his family, marriage, procreation, motherhood, child-bearing and education among other matters. No one can publish anything concerning the above matters without his consent - whether truthful or otherwise and whether laudatory or critical. The relationship between Articles 19 and 21 to be one of mutual exclusion was construed by Chief Justice Kania, speaking for a majority of five of the Bench of six judges, in A K Gopalan v State of Madras ${ }^{28}$. It was held that the seven freedoms of Article 19 were not subsumed in the fabric of life or personal liberty in Article 21 and Free speech and expression were guaranteed by Article 19(1) (a) and was hence excluded from personal liberty under Article 21.

The theory that fundamental rights are water-tight compartments was discarded by Landmark R. C. Cooper Case $^{29}$ Enumeration in Article 19 does not deprive Article 21 of its expansive ambit was ruled by courtinManeka Gandhi v. Union of India ${ }^{30}$. ADM Jabalpur vs. ShivkantSahay, 1976, Supreme Court refused to enforce the fundamental rights. Right to liberty was abolished Supreme Court gave authority to state to crack down upon dissenting voices, as it was the era of emergence. In Suresh Kumar vs. NAZ foundation, 2013 section 377 of IPCwas recriminalized .The Supreme Court decriminalized consensual intercourse between persons of the same sex and read down section 377 of the Indian Penal Code, thus providing a huge boost to the LGBT community of India. In Navjet Singh Johor v. union of India the court recognized sexual orientation as a" natural and inherent" and biological phenomenon and not matter of choice.

The individual's identity to the pedestal of divinity - sans identity, the name is only a denotative term, and the sustenance of identity is the filament of life. The destruction of individual identity would tantamount to the crushing of dignity, which encapsulates privacy, choice, freedom of speech and other expressions. The sexual orientation of each individual in the society must be protected on an even platform, for the right to privacy and protection of sexual orientation which lies at the core of the fundamental rights guaranteed by article 14,15 , and 21

\footnotetext{
${ }^{25} 1964$ SCR (1) 332

${ }^{26}$ AIR 1963 SC 1295: (1963) 2 Cri LJ 329

271994 SCC (6) 632.

${ }^{28}$ AIR 1950 SC 27

${ }^{29}$ (1978) 1 SCC 248)

${ }^{30}$ 1970) 1 SCC 248),
} 


\section{GAP GYAN - $\begin{aligned} & \text { An International Peer-Reviewed } \\ & \text { Open Access Journal of Social Sciences }\end{aligned}$}

of the constitution. A Privacy as a constitutionally protected fundamental right, was acknowledge and seen namely, in Gobind v. State of Madhya Pradesh ${ }^{31}$, PUCL v. Union of India (telephone tapping case) and R. Rajagopal v. State of Tamil Nadu ${ }^{32}$ where the Court dealt with a conflict between the freedom of the press and the right to privacy the norms for and compilation of demographic biometric data by government which was questioned on the ground that it violated the right to privacy in Aadhaar Scheme Case, Bench of three judges of this Court, while considering the constitutional challenge to the Aadhaar card scheme of the Union government. This scheme was criticized as it violated privacy. The Central government opposed the classification of privacy as a fundamental right. The government's opposition to the right relied on two early decisions-MP Sharma vs. Satish Chandra in 1954, and Pradesh in 1962 - which had held that privacy was not a fundamental right.

Recently the Supreme Court has declared the Aadhar act, 2016, constitutionally valid. In a 4: 1 verdict, the Supreme Court found that the Aadhar act, 2016 was constitutionally valid. However, the court struck down some sections of the act, including section 33(2), 47 and 57. The Aadhaar (targeted delivery financial and other subsidies, benefits and services) act, 2016 is a money bill of the parliament of India. 5-member constitution bench of the Supreme Court rules that Aadhar is mandatory for filing using Aadhar card and had warned account holders that their services will be blocked in case of failure. Now they cannot seek Aadhar details. Puttaswamy vs. Union of India, 2017 it is 9 judgesbench headed by chief justice of India verdict right to privacy is a fundamental right not mentioned anywhere in the constitution intrinsic derived implied. Article 21 of right to life and personal liberty.

Earlier elevation was it is statutory right and can be amended easily. But now 9 bench judges overturned 8 bench judge judgments and said it as constitutional right. Part of Basic Structure. Right to left alone included the left alone physically and digitally. Neither the state nor constitution gives this right they are part of natural law available to human beings. Privacy means right to be different having different beliefs having different practices and heterogeneity.

The constitutional makers might not have intended to include the said right in the Constitution, but the technology we are experiencing today is far different and advanced from the lives of generations who drafted the constitution, so there is a need for change in the method of a resolution for the newly emerging problems so the solutions must undergo a process of re-engineering. Right to privacy has been postulated in both positive and negative content. The negative content restrains the state from committing an intrusion upon the life and personal liberty of a citizen. Its positive content imposes an obligation on the state to take all necessary measures to protect the privacy of the individual. As of now, there isn't any specific and certain laws for the protection of privacy, the private bills on Privacy Laws are still pending in the Parliament. But there are certain provisions in the IT Act, 2000 under Section 43A; the government framed eight rules to protect the privacy of an individual. These all relate to seeking permission from a company before accessing privacy data of individuals and fixing liabilities for violation of the same.

\footnotetext{
${ }^{31}(19752$ SCC 14),

${ }^{32}((1994) 6$ SCC 632
} 


\section{GAP GYAN - An International Peer-Reviewed Open Access Journal of Social Sciences}

Apart from it, Right to Information Act, 2005, the Indian Easements Act, 1882, The Indian Penal Code, 1860, The Indian Telegraph Act, 1885, the Bankers' Books Evidence Act, 1891, the Credit Information Companies (Regulation) Act, 2005, the Public Financial Institutions (Obligation as to Fidelity and Secrecy) Act, 1983, the Payment and Settlement Systems Act, 2007, the Income Tax Act, 1961, the Aadhaar (Targeted Delivery of Financial and other Subsidies, Benefits and Services) Act, 2016, the Census Act, 1948, the Collection of Statistics Act, 2008, the Juvenile Justice (Care and Protection of Children) Act, 2015, the Protection of Children from Sexual Offences Act, 2012 and the Information Technology Act, 2000 have provisions relating to protection of privacy of individuals in the country.

\section{CONCLUSION}

The topic of right to privacy has even super dynamic with changing time. The evolution has been seen since last 60 years and for the interpretation of the right to privacy which is intrinsically given in under article; help of the definition of international favour has been taken. The various judgments from starting till day has been under the clutches of the majority game of benches of the judges so to prevent that, and also taking into the consideration of the need of the time, that is when the framers of the Constitution framed the laws and need of the present technology era where perception and need of privacy has arisen, the approach matching the present need of time need to be taken regarding privacy laws. 